https://doi.org/10.15407/ukrbotj76.03.252

\title{
First records of Erysiphe corylacearum (Erysiphales, Ascomycota) on Corylus avellana in Ukraine
}

\author{
Vasyl P. HELUTA ${ }^{1}$, Nataliya V. MAKARENKO², Galeb A. AL-MAALI ${ }^{1}$ \\ ${ }^{1}$ M.G. Kholodny Institute of Botany, National Academy of Sciences of Ukraine \\ 2 Tereschenkivska Str., Kyiv 01004, Ukraine \\ vheluta@botany.kiev.ua \\ ${ }^{2}$ M.M. Gryshko National Botanical Garden, National Academy of Sciences of Ukraine \\ 1 Tymiryazevska Str., Kyiv 01014, Ukraine \\ mmnv@ukr.net
}

Heluta V.P., Makarenko N.V., Al-Maali G.A. 2019. First records of Erysiphe corylacearum (Erysiphales, Ascomycota) on Corylus avellana in Ukraine. Ukrainian Botanical Journal, 76(3): 252-259.

Abstract. Information on the records of a new adventive powdery mildew fungus Erysiphe corylacearum (Erysiphales, Ascomycota) in Ukraine is provided. The fungus was found on Corylus avellana (Betulaceae) in Kyiv, as well as in Crimea. Current distribution of this species outside its primary range is analyzed. It has been shown that the fungus came to Ukraine from the East through the Caucasus. Ukrainian specimens were compared with samples collected in the Far East of Russia. It was found that Ukrainian specimens have slightly larger chasmothecia, somewhat more numerous asci, which are slightly more elongated and often short stalked. It is noted that the fungus has a great invasive potential and in the future can cause considerable damage to the forestry of European countries. The article is illustrated with micrographs obtained under light and scanning electron microscopes.

Keywords: alien species, Erysiphe corylicola, hazelnut, invasion, powdery mildew

Submitted 20 February 2019. Published 11 July 2019

Гелюта В.П. ${ }^{1}$, Макаренко Н.В. ${ }^{2}$, Аль-Маалі Г.А. ${ }^{1}$ 2019. Перші знахідки Erysiphe corylacearum (Erysiphales, Ascomycota) на Corylus avellana в Україні. Український ботанічний журнал, 76(3): 252-259.

${ }^{1}$ Інститут ботаніки ім. М.Г. Холодного НАН України

вул. Терещенківська 2, Київ 01004, Україна

${ }^{2}$ Національний ботанічний сад ім. М.М. Гришка НАН України

вул. Тимірязєвська 1, Київ 01014, Україна

Реферат. Наводиться інформація про знахідки в Україні нового адвентивного борошнисторосяного гриба Erysiphe corylacearum (Erysiphales, Ascomycota). Гриб виявлено на Corylus avellana (Betulaceae) у м. Києві, а також в Криму. Аналізується новітнє поширення цього виду поза межами його первинного ареалу. Показано, що гриб потрапив в Україну зі Сходу через Кавказ. Порівнюються українські матеріали зі зразками, зібраними на Далекому Сході Росії. Встановлено, що вони мають дещо більші хазмотеції, більшу кількість сумок, останні більш витягнуті, частіше на маленькій ніжці. Зазначається, що гриб має значний інвазійний потенціал і в майбутньому може завдавати помітної шкоди лісовому господарству європейських країн. Стаття проілюстрована зображеннями, отриманими за допомогою світлового та скануючого електронного мікроскопів.

Ключові слова: адвентивний вид, борошниста роса, інвазія, ліщина, Erysiphe corylicola

\section{Introduction}

The list of powdery mildews (Erysiphales, Ascomycota) in Ukraine is being continuously expanded both through the study of complex species and their subsequent splitting, as well as through the migration to Europe of the alien representatives of this order, primarily from North America and East Asia. Thus, for example, within the species complex Golovinomyces cichoracearum (DC.) Heluta, a several segregate species have been proposed (Cook, Braun, 2009; Braun, Cook, 2012), of which G. ambrosiae (Schwein.) U.Braun \& R.T.A.Cook, G. asterum (Schwein.) U.Braun,

(C) 2019 V.P. Heluta, N.V. Makarenko, G.A. Al-Maali. Published by the M.G. Kholodny Institute of Botany, NAS of Ukraine. This is an open access article under the terms of the Creative Commons Attribution License (http://creativecommons.org/licenses/by/4.0/), which permits use, distribution, and reproduction in any medium, provided the original work is properly cited 
G. inulae U.Braun \& H.D.Shin, G. macrocarpus (Speer) U.Braun, G. senecionis U Braun, G. sonchicola U.Braun \& R.T.A.Cook, and G. spadiceus (Berk. \& M.A.Curtis) U.Braun are also recorded in Ukraine. In less than two decades of the 21st century, such species as Erysiphe azaleae (U.Braun) U.Braun \& S.Takam. (Heluta et al., 2004a), E. elevata (Burrill) U.Braun \& S.Takam. (Heluta et al., 2009a), E. flexuosa (Peck) U.Braun \& S.Takam. (Heluta, Voytyuk, 2004), E. platani (Howe) U.Braun \& S.Takam. (Heluta et al., 2013), E. salmonii (Syd. \& P.Syd.) U. Braun \& S.Takam. (Heluta et al., 2017), E. symphoricarpi (Howe) U.Braun \& S.Takam. (Heluta et al., 2016b), Golovinomyces greeneanus (U.Braun) Heluta (Heluta, Korytnianska, 2011) and Podosphaera amelanchieris Maurizio (Heluta, Hirylovich, 2016) have been introduced to Ukraine from North America, but on the other hand, E. kenjiana (Homma) U.Braun \& S.Takam. (Heluta et al., 2009b), E. macleayae R.Y.Zheng \& G.Q.Chen (Heluta, Kravchuk, 2015; Heluta et al., 2016a), E. magnifica (U.Braun) U.Braun \& S.Takam. (Palahecha, Chumak, 2011), E. syringaejaponicae (U. Braun) U.Braun \& S.Takam. (Seko et al., 2008, 2011), Neoerysiphe geranii (Y.Nomura) U.Braun (Heluta, 2001; Heluta et al., 2010) and Podosphaera parietariae (Schwarzman) U.Braun \& S.Takam. (Heluta et al., 2004b) originated from East and Central Asia. Nowadays, the process of expansion of the species diversity of powdery mildews continues. In this paper, we report another new alien (adventive) species in Ukraine, Erysiphe corylacearum U.Braun \& S.Takam. found by the authors in 2017 and 2018 (two localities) on Corylus avellana L. (Betulaceae) in Kyiv.

\section{Materials and methods}

In 2017, during the survey of ornamental plantings in the M.M. Gryshko National Botanical Garden, National Academy of Sciences of Ukraine, the authors of the article collected leaves of Corylus avellana amphigenously infected with powdery mildew. Almost simultaneously, similar specimens were collected in another locality, in the courtyard of M.G. Kholodny Institute of Botany, National Academy of Sciences of Ukraine, where this plant has been cultivated for many years as ornamental. For comparison, samples of Erysiphe corylacearum from the Far East of the Russian Federation were also examined. They were collected by the first author in late September - early October 1989 near Vladivostok and in Kedrovaya Pad Nature Reserve on Corylus heterophylla, which is a typical host plant for this powdery mildew fungus. To study the

Український ботанічний журнал, 2019, 76(3) fungus, herbarium materials were used. Samples for light microscopy were prepared by standard methods in distilled water. However, in order to restore the original shape and size of conidia, they were put in a droplet of $40 \%$ lactic acid solution on a microscope slide, covered with a cover glass, gently heated to boiling point, then studied and photographed under a light microscope "Primo Star" (Carl Zeiss, Germany) with the camera "Canon A 300" and the software "AxioVision 4.7". The SEM micrographs were obtained with a Jeol JSM6060LA (Tokyo, Japan) scanning electron microscope (SEM). Dry pieces of leaf with mycelium and ascomata were glued to metallic stubs and sputter-coated with gold under vacuum. The obtained digital data were processed statistically. For each morphological feature, 30 structures were measured. Limits of variation were determined as $\mathrm{M} \pm 1.96 \sigma$, where $\mathrm{M}$ is a simple average and $\sigma$ is a standard deviation. The specimens were deposited at KW-M (abbreviation according to Index Herbariorum, http://sweetgum.nybg.org/ science/ih/) and in personal mycological herbarium of N.V. Makarenko (M.M. Gryshko National Botanical Garden, National Academy of Sciences of Ukraine).

\section{Results and discussion}

Common hazel (Corylus avellana L.) is naturally distributed throughout Ukraine and in other European countries, in Asia Minor, and in northern Iran. This plant is widely used in forestry as an underwood species in forest stands. In addition, it is grown as an ornamental crop in botanical gardens and parks of settlements. Hazelnuts are used for food (Kokhno et al., 1986; Kosenko, 2002; Slyusarchuk, 2005).

In Ukraine, common hazel is very often infected by powdery mildew caused by Phyllactinia guttata (Wallr.) Lév. Mycelium of this fungus develops initially endophytically, in the leaf mesophyll. Only at the end of summer, through stomata, it grows out to the lower surface of the leaf. Right here the mycelium forms the conidial stage of the fungus, and later produces fruiting bodies known as chasmothecia. In these two stages, the fungus is easily detected, since it forms large, grayish spots that can merge into one continuous mycelial layer. Obviously, this disease does not cause significant damage to the host, as it develops intensively only in the autumn, at the end of plant vegetation. However, examining the green plantations of the M.M. Gryshko National Botanic Garden of the National Academy of Sciences of Ukraine, we discovered the common hazel bush with the leaves affected by a powdery mildew on 


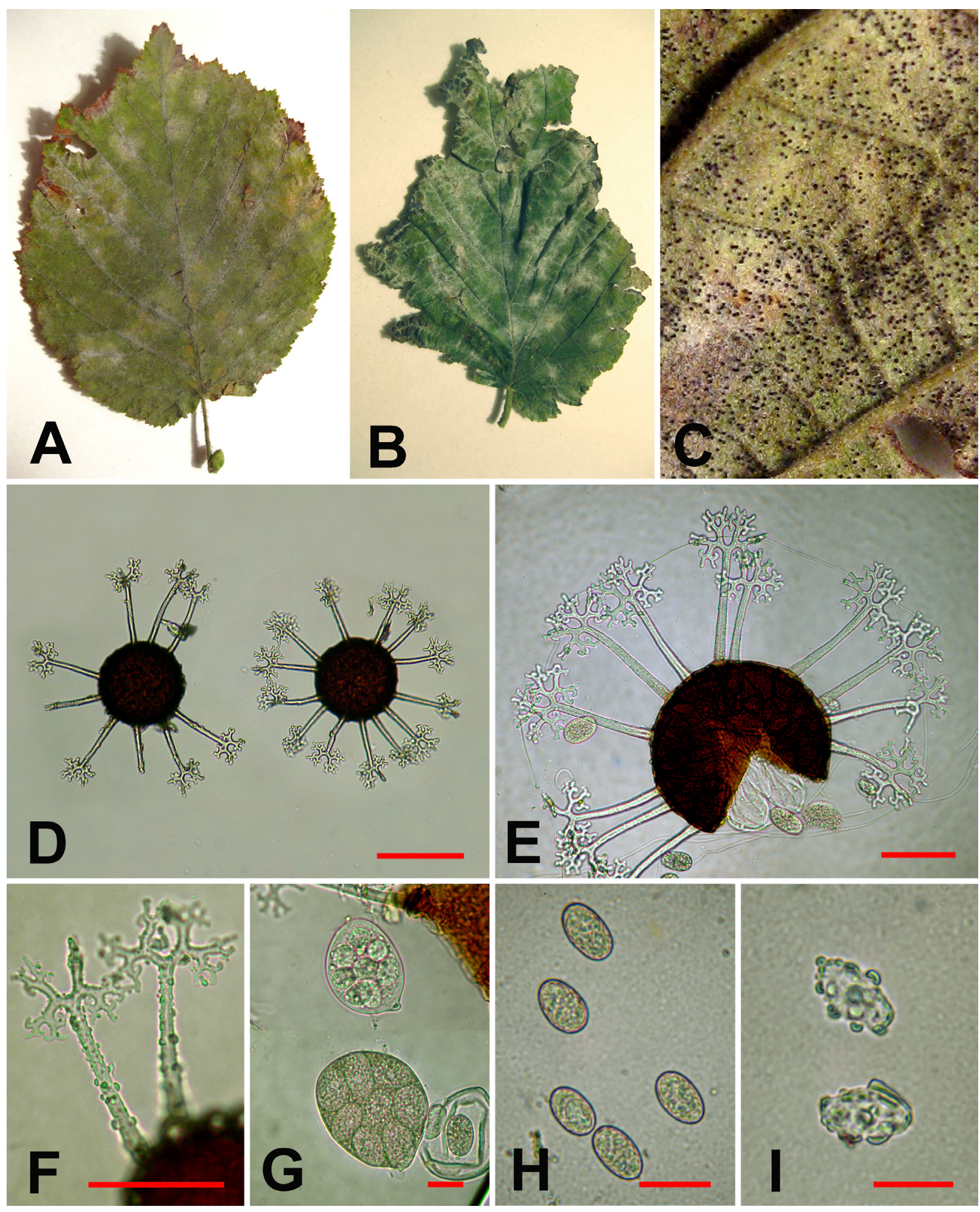

Fig. 1. Erysiphe corylacearum on Corylus avellana. A, B: infected leaves; C: chasmothecia on the underside of the leaf; D, E: chasmothecia with appendages; F: appendages after heating in a solution of lactic acid; G: asci (the lower ascus is flattened by a cover glass); H: ascospores; I: conidia after heating in a solution of lactic acid. Bars: $100 \mu \mathrm{m}$ (D), $50 \mu \mathrm{m}(\mathrm{E}-\mathrm{F}), 20 \mu \mathrm{m}(\mathrm{G}-\mathrm{I})$ 

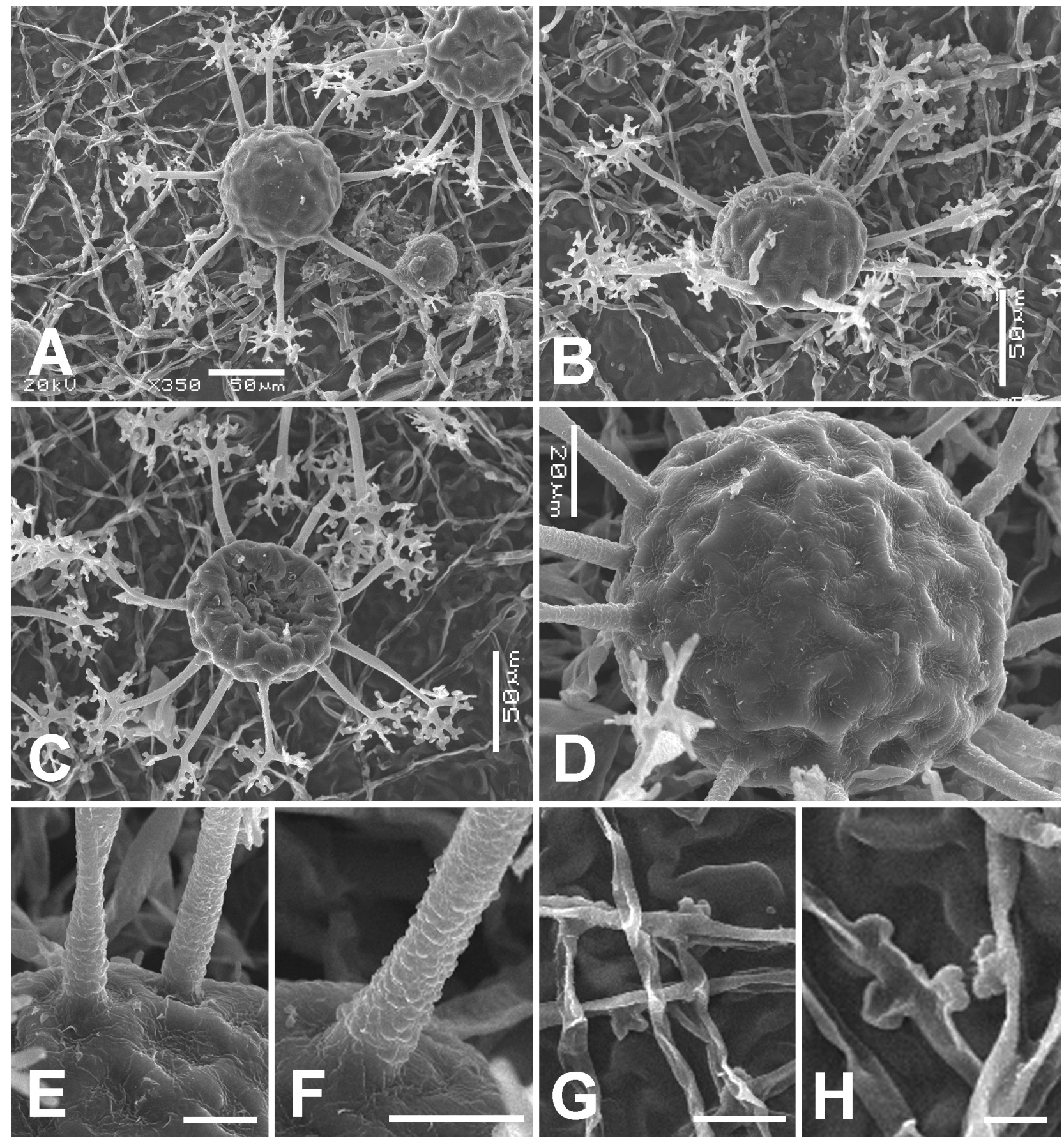

Fig. 2. Erysiphe corylacearum on Corylus avellana (SEM). A-C: chasmothecia with appendages, view from different angles (A: top view, B: slightly side view, C: bottom view); D: surface of the chasmothecium; E-F: basal parts of the appendages; G-H: mycelial hyphae with lobed $(\mathrm{G})$ and unlobed $(\mathrm{H})$ appressoria. Bars: $50 \mu \mathrm{m}(\mathrm{A}-\mathrm{C}), 20 \mu \mathrm{m}(\mathrm{D}), 10 \mu \mathrm{m}(\mathrm{E}-\mathrm{H})$ 
both sides (Fig. 1, A-C). It immediately became clear that we found another fungus causing this disease, still unknown in Ukraine. In a microscopic study, it was found that fruit bodies of the fungus have appendages with dichotomously branched apices and several asci in the chasmothecium (Fig. 1, D, E; 2, A-C). Thus, the species belongs to the section Microsphaera (Lév.) U.Braun \& Shishkoff of the genus Erysiphe R.Hedw. ex DC., and it was identified as E. corylacearum. Below is a description of the material we have collected.

Erysiphe corylacearum U.Braun \& S.Takam., in Braun, Schlechtendalia 8: 33.2002 (Fig. 1, 2).

Syn.: Microsphaera penicillata f. coryli Jacz., Karm. opred. gribov. Vyp. 2. Muchnisto-rosianye griby. Leningrad: 350. 1927. - Microsphaera coryli (Jacz.) Golovin, Trudy Bot. inst. Akad. nauk SSSR, ser. 2, vyp. 10: 336. 1956, nom. illeg. - Microsphaera hommae U.Braun, Mycotaxon 15: 124. 1982. Erysiphe hommae (U.Braun) U.Braun \& S.Takam., Schlechtendalia 4: 9. 2000, nom. illeg.

Mycelium amphigenous, grayish, forming mostly indistinct, sometimes white, rather clear patches, on the lower side of the leaves less developed. Hyphae $4.0-6.5 \mu \mathrm{m}$ thick, hyphal appressoria mostly solitary or occasionally in opposite pairs, simple or lobed. Conidia doliiform, limoniiform, short, 20-29 × 10-16 $\mu \mathrm{m}$, formed singly. Chasmothecia scattered to gregarious, hemispherical, depressed in the lower part, 82-113 $\mu \mathrm{m}$ in diam. Peridial cells polygonal, rounded, not very distinct, about $10-20 \mu \mathrm{m}$ in diam. Appendages 6-14, equatorial, straight, short (0.6-1.2 times as long as the chasmothecial diam.), about 6.5-8.0 $\mu \mathrm{m}$ near the base and $4.5-6 \mu \mathrm{m}$ in the apical part, colourless, more or less rough, aseptate, sometimes at the base dichotomously branched, apices 3-5 times densely and regularly branched, tips recurved. Asci 3-7, broadly-ellipsoid, obovoid, 44-55 × 33-41 $\mu \mathrm{m}$, mostly sessile or on a very short stalk (up to $6.5 \mu \mathrm{m}$ ), $6-8$-spored. Ascospores ellipsoidal, ovoid, 17-21 × 10.0-14.5, colourless.

Specimens examined. On Corylus avellana L.: Kyiv, M.M. Gryshko National Botanical Garden, 22.09.2017, V. Heluta, N. Makarenko (KW-M71165M); ibidem, 10.11.2017, N. Makarenko (KW-M71167M); 28 Velyka Zhytomyrska Str., courtyard of M.G. Kholodny Institute of Botany of the National Academy of Sciences of Ukraine, 26.09.2017, G. Al-Maali (KW-M71172M). On C. heterophylla Fisch. ex Trautv.: Russian Federation, Primorsky Kray, outskirts of Vladivostok, coast of Lazurnaya Bay (Shamora), 26.09.1989, V. Heluta (KW-M71168M); Primorsky Kray, Khasan District,
Kedrovaya Pad Reserve, 02.10.1989, V. Heluta (KWM71170M).

A comparison of the characteristics of the fungus collected on $C$. avellana in Ukraine with those in the description of $E$. corylacearum, as provided in the monograph by U. Braun and R. Cook (2012), shows that Ukrainian specimens are entirely within the range of variation of this species. We also compared these specimens with the samples collected in 1989 by the first author in the territory of the primary range of this species. As a result, it turned out that the Ukrainian and Far Eastern materials are slightly different according to some characters. Samples from Ukraine had somewhat larger fruit bodies, therefore, the ratio of the appendage length and the diameter of the chasmothecium varied and the appendages seemed to be shorter. In addition, we observed larger number of asci in the fruit body (3-7 instead of 2-4) and their slightly different shape: asci were slightly elongated and almost all of them had a short stalk (Fig. 1, G). When heated in a solution of lactic acid, conidia and stems of the appendages of E. corylacearum are covered with well-visible bubbles (Fig. 1, F, I). This phenomenon was observed only in a number of species of the genus Leveillula G.Arnaud.

Erysiphe corylacearum has long been known in North America, where it was considered a part of the huge complex Microsphaera penicillata s.l. (Salmon, 1900). This fungus as a separate taxon was obviously first mentioned by A.A. Jaczewski (1927), who considered it as M. penicillata f. coryli Jacz. Later P.M. Golovin (1956), based on this form, proposed a new speciesrank combination, Microsphaera coryli (Jacz.) Golovin. However, this combination was illegitimate, since at that time under the same name a morphologically different powdery mildew has already been described, namely Microsphaera coryli Homma, found in Japan on Corylus heterophylla. That is why U. Braun (1982), based on the Japanese specimen, validly described the fungus we report in this article, as $M$. hommae. Over time, due to the results of molecular phylogenetic studies, the genus Microsphaera Lév. was included in Erysiphe and a new combination E. hommae (U.Braun) U.Braun \& S. Takam was proposed (Braun, Takamatsu, 2000). However, this combination also proved to be illegitimate, since at that time under the same name another powdery mildew fungus, Erysiphe hommae U.Braun, parasitizing a host from the Lamiaceae has been already described. In view of the above, for the fungus parasitizing hazel, a new name E. corylacearum U.Braun \& S.Takam. has been proposed (Braun, 2002). Almost until recently, this 
species was known in North America (Canada, USA) and Asia (China, Korea, Far East of Russia, Japan) on a number of species of the genus Corylus L., but C. avellana was not listed among the host plants (Braun, Cook, 2012). Thus, E. corylacearum is an East AsianNorth American fungus by its origin.

As previously noted (Heluta et al., 2016b), alien species of powdery mildews enter the territory of Ukraine by different pathways. North American fungi migrate through Western Europe, and East Asian species from the opposite direction. As for E. corylacearum, we have a unique case, since it is at the same time an East Asian and a North American species. So, the question arises, where and how has this powdery mildew got to Ukraine?

Due to analysis of literature information, it becomes clear that over the past few years E. corylacearum has gone beyond its original range. In 2013, the fungus was recorded in Turkey (Sezer et al., 2017), in 2016 in Azerbaijan (Abasova et al., 2018), in 2017 in Iran (Arzanlou et al., 2018). It was noted that in Turkey, this powdery mildew spread very quickly in the Black Sea regions and now it causes significant damage to host plants. A similar pattern is observed in Iran, where the damage to plants is also significant. The fungus is found there in the provinces of Ardebil and Eastern Azerbaijan, which adjoin Azerbaijan and are located near Turkey. It is also reported that in 2016 E. corylacearum was found in Bakhchysaray District of the Autonomous Republic of Crimea (Ukraine), and from 2017 it is recorded in the north of Krasnodar and Rostov regions of Russia (Bulgakov, 2018). It is worth noting that the first three articles mentioned are well illustrated, the species was identified using molecular methods, and therefore it is undoubtedly the same fungus. Thus, over the large area we observe the invasion of the East Asian-North American powdery mildew fungus $E$. corylacearum.

In addition, there are several reports (Churakov et al., 2014, 2015; Khuseyin et al., 2014; Karpun et al., 2016) of the finds, also outside of the range, of another parasite of hazel, E. corylicola U.Braun \& S.Takam. The fungus was reported from Turkey and the Russian Federation (two records in Ulyanovsk Region and extensive development in Adler, Krasnodar Region). However, taking into account that this species is endemic in Japan, its records beyond the native range should be considered extremely unlikely. Obviously, the materials on which these reports were based were incorrectly identified. Unfortunately, the authors did not give any description or illustrations of the collected samples. However, Adler is not far from Azerbaijan and Turkey, and the distance from Adler to Ulyanovsk is not critical for distribution of powdery mildew fungi. Therefore, it is much more likely that in all cases the authors dealt with E. corylacearum, and not with $E$. corylicola. In any case, since representatives of the genus Erysiphe on hazelnut have not yet been recorded in the western part of Ukraine, we come to the conclusion that E. corylacearum migrated to Ukraine from the eastern or southeastern direction, through the Caucasus.

At present, we know only three localities of E. corylacearum in Ukraine. Additional search for this fungus in Kyiv and adjacent regionswere unsuccessful. However, in accordance with the epiphytotic nature of the development of E. corylacearum in Iran and Turkey, we should expect a significant spread of powdery mildew of hazel in Ukraine.

Thus, another alien powdery mildew fungus with a high invasive potential, E. corylacearum, is recorded in Europe. The spread and development of this species can cause significant damage to ornamental plantations and lead to large losses on farms producing hazelnuts.

\section{Acknowledgements}

We thank Dr. Vera Hayova for help in editing English and valuable comments on the manuscript. We also gratefully acknowledge Ms. N.S. Novychenko, for her help with scanning electron microscopy.

\section{REFERENCES}

Abasova L.V., Aghayeva D.N., Takamatsu S. 2018. Notes on powdery mildews of the genus Erysiphe from Azerbaijan. Current Research in Environmental \& Applied Mycology, 8(1): 30-53. https://doi.org/10.5943/cream/8/1/3

Arzanlou M., Torbati M., Golmohammadi H. 2018. Powdery mildew on hazelnut (Corylus avellana) caused by Erysiphe corylacearum in Iran. Forest Pathology, 48(5): $1-4$.

Braun U. 1982. Descriptions of new species and combinations in Microsphaera and Erysiphe (II). Mycotaxon, 15: 121-137.

Braun U. 2002. Miscellaneous notes on some micromycetes (II). Schlechtendalia, 8: 33-38.

Braun U., Cook R.T.A. 2012. Taxonomic manual of the Erysiphales (powdery mildews). Utrecht: CBS-KNAW Fungal Biodiversity Centre, $707 \mathrm{pp}$.

Braun U., Takamatsu S. 2000. Phylogeny of Erysiphe, Microsphaera, Uncinula (Erysipheae) and Cystotheca, Podosphaera, Sphaerotheca (Cystothecaeae) inferred from rDNA ITS sequences - some taxonomic consequences. Schlechtendalia, 4: 1-33.

Bulgakov T.S. 2018. In: $X$ Chteniya pamyati O.A. Kataeva. Dendrobiontnye bespozvonochnye zhivotnye i griby i ikh 
rol v lesnykh ekosistemakh, vol. 2. Fitopatogennye griby, voprosypatologii izashchitylesa:materialymezhdunarodnoy konferentsii. Sankt-Peterburg, 22-25 oktyabrya 2018 g. Eds D.L., Musolina, A.V. Selikhovkina. SPb.: SPbGLTU, pp. 11-12. [Булгаков Т.С. 2018. Инвазии чужеродных фитопатогенных грибов на юге европейской части России в XXI веке: мучнисторосяные грибы на деревьях и кустарниках. В кн.: Х Чтения памяти О.А. Катаева. Дендробионтные беспозвоночные животные $и$ грибы и их роль в лесных экосистемах, m. 2. Фитопатогенные грибы, вопросы патологии и защиты леса: материалы международной конференции. Санкт-Петербург, 22-25 октября 2018 г. Под ред. Д.Л. Мусолина, А.В. Селиховкина. СПб: СПбГЛТУ, с. 11-12].

Churakov B.P., Khuseyn E.S., Selchuk F., Kornilin K.E., Romanova T.A. 2015. In: Bioraznoobrazie i ekologiyagribov i gribopodobnykh organizmov severnoy Evrazii: materialy Vserossiyskoy konferentsii s mezhdunarodnym uchastiem, Ekaterinburg, 20-24 aprelya 2015. Ekaterinburg: Izd-vo Uralskogo universiteta, pp. 273-276. [Чураков Б.П., Хусейн Э.С., Сельчук Ф., Корнилин К.Е., Романова Т.А. 2015. Предварительный конспект микобиоты микромицетов лесов Ульяновской области. В сб.: Биоразнообразие и экология грибов и грибоподобных организмов северной Евразии: материалы Всероссийской конференции с международным участием, Екатеринбург, 20-24 апреля 2015 г. Екатеринбург: Изд-во Уральского университета, с. 273-276].

Churakov B.P., Mitrofanova N.A., Kornilin K.E., Romanova T.A. 2014. Izvestiya Samarskogo nauchnogo tsentra Rossiyskoy akademii nauk, 161(3): 896-899. [Чураков Б.П., Митрофанова Н.А., Корнилин К.Е., Романова Т.А. 2014. Микромицеты лесов Кандалинского и Кузоватовского лесничеств Ульяновской области. Известия Самарского научного центра Российской академии наук, 161(3): 896-899].

Cook R.T.A., Braun U. 2009. Conidial germination patterns in powdery mildews. Mycological Research, 113: 616-636.

Golovin P.N. 1956. Trudy Botanicheskogo instituta AN SSSR. Seriya 2. Sporovye rasteniya, 10: 309-366. [Головин П.Н. 1956. Материалы к монографии мучнисто-росяных грибов (сем. Erysiphaceae) в СССР. Труды Ботанического института АН СССР. Серия 2. Споровые растения, 10: 309-366].

Heluta V.P. 2001. Ukrainian Botanical Journal, 58(2): 239242. [Гелюта В.П. 2001. Neoerysiphe geranii (Y.Nomura) U.Braun - новий для України вид борошнисторосяного гриба. Український ботанічний журнал, 58(2): 239-242].

Heluta V.P., Dzyunenko O.O., Cook R.T.A., Isikov V.P. 2009a. New records of Erysiphe species on Catalpa bignonioides in Ukraine. Ukrainian Botanical Journal, 66(3): 346-353.

Heluta V.P., Hirylovich I.S. 2016. First records of an invasive fungus Podosphaera amelanchieris (Erysiphales) in Belarus and Ukraine. Ukrainian Botanical Journal, 73(1): 78-83.

Heluta V.P., Korytnyanska V.H. 2011. Ukrainian Botanical Journal, 68(5): 773-779. [Гелюта В.П., Коритнян- ська В.Г. 2011. Golovinomyces greeneanus (U.Braun) Heluta (Erysiphales) - новий для України вид борошнисторосяних грибів. Український ботанічний журнал, 68(5): 773-779].

Heluta V.P., Korytnianska V.G., Akata I. 2013. Distribution of Erysiphe platani (Erysiphales) in Ukraine. Acta Mycologica, 48(1): 105-112.

Heluta V.P., Kovalchuk V.P., Chumak P.Ya. 2016a. First records of teleomorph of an invasive fungus Erysiphe macleayae (Erysiphales) in Ukraine. Ukrainian Botanical Journal, 73(3): 268-272.

Heluta V.P., Siahaan S.A.S., Takamatsu S. 2016b. Erysiphe symphoricarpi (Erysiphales), the first record in Ukraine. Ukrainian Botanical Journal, 73(6): 604-611. https:// doi.org/10.15407/ukrbotj73.03.268

Heluta V.P., Kravchuk O.O. 2015. Ukrainian Botanical Journal, 72(1): 39-45. [Гелюта В.П., Кравчук О.О. 2015. Перші знахідки в Україні нового інвазійного гриба Erysiphe macleayae (Erysiphales). Український ботанічний журнал, 72(1): 39-45]. https://doi. org/10.15407/ukrbotj72.01.039

Heluta V., Takamatsu S., Harada M., Voytyuk S. 2010. Molecular phylogeny and taxonomy of Eurasian Neoerysiphe species infecting Asteraceae and Geranium. Persoonia, 24: 81-92.

Heluta V.P., Takamatsu S., Siahaan S.A.S. 2017. Erysiphe salmonii (Erysiphales, Ascomycota), another East Asian powdery mildew fungus introduced to Ukraine. Ukrainian Botanical Journal, 74(3): 212-219. https:// doi.org/10.15407/ukrbotj74.03.212

Heluta V.P, Takamatsu S., Voytyuk S.O., Shiroya Y. 2009b. Erysiphe kenjiana (Erysiphales), a new invasive fungus in Europe. Mycological Progress, 8(4): 367-375.

Heluta V.P., Voytyuk S.O. 2004. Ukrainian Botanical Journal, 61(5): 17-25. [Гелюта В.П., Войтюк С.О. 2004. Uncinula flexuosa Peck. - новий для України вид інвазійного борошнисторосяного гриба (Erysiphales). Український ботанічний журнал, 61(5): 17-25].

Heluta V.P., Voytyuk S.O., Chumak P.Ya. 2004a. Ukrainian Botanical Journal, 61(2): 27-33. [Гелюта В.П., Войтюк С.О., Чумак П.Я. 2004a. Microsphaera azaleae U. Braun - новий для України вид борошнисторосяного гриба (Erysiphales). Український ботанічний журнал, 61(2): 27-33].

Heluta V., Wasser S., Voityuk S. 2004b. Sphaerotheca parietariae (Erysiphales, Eumycota), a new powdery mildew fungus in Europe. Flora Mediterranea, 14: 285-289.

Jaczewski A.A. 1927. Karmannyi opredelitel gribov. Vypusk vtoroy. Muchnisto-rosyanye griby. Leningrad, $626 \mathrm{pp}$. [Ячевский А.А. 1927. Карманный определитель грибов. Выпуск второй. Мучнисто-росяные грибы. Ленинград, 626 с.].

Karpun N.N., Klemeshova K.V., Protsenko V.E. 2016. In: Sbornik statey III Vserossiyskoy nauchno-prakticheskoy konferentsii (30 noyabrya - 2 dekabrya 2016 g., Sochi), vol. 3. Sochi: Donizdat, pp. 123-128. [Карпун H.H., Клемешова К.В., Проценко В.Е. 2016. Результаты фитосанитарного и дендрологического мониторинга насаждений природного орнитологического 
парка в Имеретинской низменности. Устойчивое развитие особо охраняемых природных территорий. В сб.: Сборник статей III Всероссийской научно-практической конференции (30 ноября - 2 декабря 2016 г., Сочи), т. 3. Сочи: Дониздат, с. 123-128].

Khuseyin E.S., Selchuk F., Churakov B.P. 2014. Ulyanovskiy mediko-biologicheskiy zhurnal, 4: 114-126. [Хусейн Э.С., Сельчук Ф., Чураков Б.П. 2014. Микромицеты деревьев и кустарников лесов провинции Дюздже (Турция) и Ульяновской области (Россия). Ульяновский медико-биологический журнал, 4: 114-126].

Kokhno N.A., Kaplunenko N.F., Minchenko N.F., Doroshenko A.K., Horb V.K., Orlov M.I., KurdyukA.M., Parkhomenko L.I., Tsikalyak H.P., Mamushkina T.S., Hordienko N.M. 1986. Derevya i kustarniki, kultiviruemye $v$ Ukrainskoy SSR. Pokrytosemennye. Kiev: Naukova Dumka, 720 pp. [Кохно Н.А., Каплуненко Н.Ф., Минченко Н.Ф., Дорошенко А.К., Горб В.К., Орлов М.И., Курдюк А.М., Пархоменко Л.И., Цикаляк Г.П., Мамушкина Т.С., Гордиенко Н.М. 1986. Деревья и кустарники, культивируемые в Украинской ССР. Покрытосеменные. Киев: Наукова думка, 720 c.].

Kosenko I.S. 2002. Naukovyi visnyk, 12.3: 13-20. [Косенко I.C. 2002. Використання видів ліщини (Corylus L.) в лісовому господарстві України. Науковий вісник, 12.3: 13-20].

Palahecha R.M., Chumak P.Ya. 2011. In: Materialy XIII Z'yizdu Ukrainskoho botananichnoho tovarystva.
Lviv: Prostir M, p. 313. [Палагеча Р.М., Чумак П.Я. 2011. Еколого-морфологічна структура суб популяції Microsphaera magnifica U. Braun (Erysiphales) та інвазійна спроможність цього гриба. В зб.: Maтеріaли ХІІІ З'їзду Українського ботанічного товариства. Львів: Простір M, с. 313].

Salmon E.S. 1900. A monograph of the Erysiphaceae. Memoirs of the Torrey Botanical Club, 9: 1-292.

Seko Y., Bolay A., Kiss L., Heluta V., Grigaliunaite B., Takamatsu S. 2008. Molecularevidenceinsupportofrecent migration of a powdery mildew fungus on Syringa spp. into Europe from East Asia. Plant Pathology, 57(2): 243250. https://doi.org/10.1111/j.1365-3059.2007.01775.x

Seko Y., Heluta V., Grigaliunaite B., Takamatsu S. 2011. Morphological and molecular characterization of two ITS groups of Erysiphe (Erysiphales) occurring on Syringa and Ligustrum (Oleaceae). Mycoscience, 52(3): 171-182.

Sezer A., Dolar F.S., Lucas S.J., Köse Ç., Gümüş E. 2017. First report of the recently introduced, destructive powdery mildew Erysiphe corylacearum on hazelnut in Turkey. Phytoparasitica, 45(4): 577-581. https://doi. org/10.1007/s12600-017-0610-1

Slyusarchuk V.E. 2005. In: Problemy lesovedeniya $i$ lesovodstva: sbornik nauchnykh trudov Instituta lesa NAN Belarusi, 63: 393-394. [Слюсарчук В.Е. 2005. История, состояние и перспективы разведения орешника в Украине. В сб.: Проблемы лесоведения и лесоводства: научные труды Института леса НАН Беларуси, 63: 393-394].

Recommended for publication by V.P. Hayova 